\title{
Recanalization after acute deep vein thrombosis
}

\author{
Recanalização após trombose venosa profunda aguda
}

Gustavo Muçouçah Sampaio Brandão ${ }^{1}$, Marcone Lima Sobreira', Hamilton Almeida Rollo

\begin{abstract}
The process of recanalization of the veins of the lower limbs after an episode of acute deep venous thrombosis is part of the natural evolution of the remodeling of the venous thrombus in patients on anticoagulation with heparin and vitamin $\mathrm{K}$ inhibitors. This remodeling involves the complex process of adhesion of thrombus to the wall of the vein, the inflammatory response of the vessel wall leading to organization and subsequent contraction of the thrombus, neovascularization and spontaneous lysis of areas within the thrombus. The occurrence of spontaneous arterial flow in recanalized thrombosed veins has been described as secondary to neovascularization and is characterized by the development of flow patterns characteristic of arteriovenous fistulae that can be identified by color duplex scanning. In this review, we discuss some controversial aspects of the natural history of deep vein thrombosis to provide a better understanding of its course and its impact on venous disease.
\end{abstract}

Keywords: venous thrombosis; ultrasonography Doppler color; review literature as topic.

\begin{abstract}
Resumo
O processo de recanalização das veias dos membros inferiores, após um episódio de trombose venosa profunda aguda em pacientes anticoagulados com heparina e inibidores da vitamina $K$, faz parte da evolução natural da remodelagem do trombo venoso. Esse complexo processo de remodelagem envolve a adesão do trombo à parede da veia, à resposta inflamatória da parede do vaso, levando à organização e subsequente contração do trombo, à neovascularização e à lise espontânea de áreas no interior do trombo. A presença de fluxo arterial espontâneo em veias com trombose recanalizada tem sido descrita como secundária à neovascularização e se caracteriza pelo desenvolvimento de fluxo com padrão de fístulas arteriovenosas, identificadas por meio de mapeamento dúplex colorido. Nesta revisão, são discutidos alguns aspectos controversos da história natural da trombose venosa profunda, para uma melhor compreensão da sua evolução e do seu impacto sobre a doença venosa.
\end{abstract}

Palavras-chave: trombose venosa; ultrassonografia Doppler em cores; literatura de revisão como assunto.

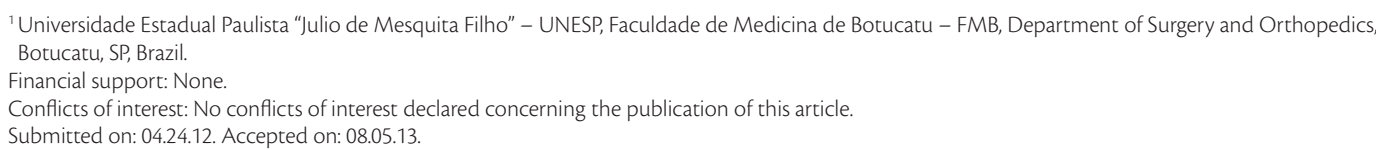




\section{INTRODUCTION}

Deep vein thrombosis (DVT) of the lower extremities (LE) is a serious and potentially fatal disease in which there is acute thrombus formation in deep veins of the LE that can cause partial or total obstruction of the venous lumen. Deep vein thrombosis is currently considered a component of the nosological entity venous thromboembolism (VTE). Venous thromboembolism is a wider designation that includes both DVT and pulmonary embolism (PE).

The pathophysiologic process of thrombus formation was described by the German pathologist Rudolf Virchow (1821-1902) in 1856. The process itself is known as thrombogenesis and its chief characteristic is a loss of normal homeostasis due to an imbalance between procoagulatory factors and natural anticoagulants. These factors can act independently or interdependently, exerting varying degrees of influence on the thrombogenic process. For example, in cases of venous trauma the predominant factor in development of thrombosis is endothelial injury, whereas in spontaneous thrombosis hypercoagulability and venous stasis are the most important thrombogenic factors.

\section{LOCATION}

The most common sites in which thrombi originate are the muscular or trunk veins of the legs, according to studies using phlebography and the labeled fibrinogen test ${ }^{1}$. The thrombi can propagate proximally to the popliteal, femoral and iliac veins, resulting in the multiple types of thrombosis that are seen in clinical practice or autopsies ${ }^{1}$. In the lower extremities, the deep veins most often involved are the external iliac, the common femoral, the deep femoral, the femoral, the popliteal, the gastrocnemius, the soleus, the posterior tibials and the fibular ${ }^{2,3}$. Both the great and small saphenous veins can also be affected by thrombosis, but since these veins are part of the superficial system this condition is known as superficial vein thrombosis $(\mathrm{SVT})^{4}$. However, the saphenous veins are connected to the deep vein system and cases of SVT can progress to $\mathrm{PE}^{5}$, and they should not therefore be ignored when investigating the deep vein system. In clinical practice, DVT of LE are generally subclassified as either proximal or distal ${ }^{1}$. They are considered proximal when they involve the iliac, femoral or popliteal veins, with or without involvement of veins in the legs, and are considered distal when they only affect veins of the legs. The importance of this differential definition is that around $46 \%$ of proximal DVT cases can progress to PE and $4 \%$ are fatal if left untreated ${ }^{1}$. Furthermore, according to Susan and Kahn, up to 50\% can develop postthrombotic syndrome ${ }^{6}$.

\section{RISK FACTORS}

The most common risk factors for DVT are: prolonged immobility, traumas, postoperative period, advanced age, pregnancy, postnatal period, obesity, malignant neoplasms, estrogen-based female hormones, hereditary thrombophilias (natural anticoagulant deficiency, factor $\mathrm{V}$ Leiden and the G20210A prothrombin mutation) and the acquired thrombophilias (hyperhomocysteinemia and the antiphospholipid antibody syndrome $)^{7}$.

\section{EPIDEMIOLOGY}

While it can affect young healthy people, DVT is uncommon before 20 years of age ${ }^{8}$ and incidence increases with age. In one review article, Fowkes et al. report the following annual incidence rates: $2-3$ per 10,000 (ages $30-49$ ), 5 per 10,000 (ages 50-59), 10 per 10,000 (ages 60 to 69) and 20 per 10,000 (ages 70 to 79 years) ${ }^{9}$. Similarly, Naess et al. ${ }^{10}$ observed three times greater incidence among 70-year-olds compared with people aged 20-44. In terms of sex distribution, DVT incidence among females was 1.58 per 1,000 per year, against 1.28 per 1,000 per year for males ${ }^{10}$. In the United States, annual mortality from $\mathrm{PE}$ has been estimated at 50,000 people and there are 300,000 to 600,000 hospital admissions for DVT and PE every year ${ }^{1}$. A population study of 94,194 people over the age of 20 from the Norwegian town of Nord-Trøndelag found that mortality from DVT within 30 days of the initial event was $6.4 \%$, that 12 -month mortality was $21.6 \%$, and that 30 -day mortality for patients with PE was twice that for patients who only had $\mathrm{DVT}^{10}$. On the basis of an analysis of hospital admission data, it has been estimated that the rate of DVT diagnosed clinically and confirmed by duplex mapping or phlebography in Brazil is six cases per 10,000 inhabitants per year ${ }^{1}$. This estimate is very close to the figure reported by Fowkes et al., who observed an incidence of DVT in the general population of five cases per 10,000 inhabitants per year'. Several authors of previous studies have also reported incidence rates that were similar or that varied slightly. Hasson et al. ${ }^{11}$ reported an adjusted incidence of 5.8 cases of DVT per 10,000 inhabitants per year. White et al. ${ }^{12}$, conducted a large-scale population study including around 18,000 DVT cases and calculated an incidence of 4.9 cases per 10,000 inhabitants per year. In another study, conducted in 
1992 in the Swedish city Malmö, Nordström et al. ${ }^{13}$ observed an incidence of 9.5 DVT cases per 10,000 inhabitants. Oger ${ }^{14}$ observed incidence of 8.7 cases of DVT for every 10,000 inhabitants per year.

\section{DIAGNOSIS}

Patients with DVT may not exhibit specific and/or pathognomonic signs and symptoms of the disease. Clinical presentation is highly variable and may be restricted to simple localized discomfort in the affected limb, and this can also be the case with the much-feared PE. While pain, edema and muscle rigidity have been identified in up to $86.7 \%$ of patients with DVT, these signs and symptoms can also present in other conditions, such as: lymphangitis , cellulites, ruptured Baker's cyst, congestive heart failure, nephrotic syndrome, traumas, muscle hematomas, myositis and muscle tears ${ }^{1}$. In view of this, a clinical diagnosis alone is not sufficient to confirm diagnosis in suspected cases of DVT ${ }^{15,16}$. Patients who go undiagnosed and are therefore treated inadequately can suffer chronic venous insufficiency (CVI) and even death caused by PE. Therefore, when faced with a clinical suspicion of DVT and a need to assess the status of a thrombosed vein in order to treat its complications, specific examinations or supplementary diagnostic methods capable of directly or indirectly demonstrating the presence and extent of the thrombus must be used. Clinical prediction models such as those proposed by Wells et al. ${ }^{17}$, in combination with laboratory D-dimer testing and imaging exams with color duplex mapping (CDM), have made it easier to reliably diagnose $\mathrm{DVT}^{18,19}$.

\section{TREATMENT}

Current recommendations on treating DVT are the same as for VTE and are based on anticoagulant therapy, as described in the 9th edition of the American College of Chest Physicians Evidence-Based Clinical Practice Guideline (ACCP) ${ }^{20}$. Initial treatment consists of parenteral administration for 5 to 7 days of unfractionated heparin (UFH), or subcutaneous administration of low molecular weight heparin (LMWH) and oral vitamin $\mathrm{K}$ antagonists (VKA), adjusting the dose to achieve a prothrombin time as close as possible to the international standard for thromboplastin, which is expressed in INR (international normalized ratio) and should remain between 2 and 3 . In addition to conventional anticoagulant therapy, the ACCP has recommended that all patients with acute symptomatic DVT should wear graduated elastic compression stockings, because of their potential to cut the rate of postthrombotic syndrome (PTS) by half ${ }^{20}$. In addition to anticoagulant treatments, some ongoing studies have suggested that pharmacological removal of acute thrombi using fibrinolytic therapies can preserve vein valve function ${ }^{21}$. The ATTRACT study has been designed to show whether the new treatment prevents the serious later complications of DVT by conducting a prospective assessment of 692 patients with symptomatic proximal thrombosis of the iliac, common femoral and femoral veins ${ }^{22}$.

\section{CLINICAL COURSE}

One feature of the natural history of DVT that remains controversial is its progression. After a DVT episode, there is an acute inflammatory response in the vein wall and in the thrombus itself, leading to a dynamic process in which the thrombus regresses due to recanalization. Recanalization is defined as the return of blood flow to a venous segment that had previously been occluded. Recanalization is a complex process that initially involves adhesion of the thrombus to the vein wall and an inflammatory response in the vessel wall, leading to organization and subsequent contraction of the thrombus, and to neovascularization and spontaneous lysis of areas inside the thrombus ${ }^{23}$. However, recanalization is not the only phenomenon observed during the natural course of DVT and propagation of the thrombus has been identified in 20 to $40 \%$ of patients monitored using CDM, despite adequate anticoagulation ${ }^{24}$. It is therefore very important to understand these pathophysiologic mechanisms because delayed regression or propagation of the thrombus may be related with development and exacerbation of the signs and symptoms of CVI.

\section{POSTTHROMBOTIC SYNDROME}

Postthrombotic syndrome (PTS) is a common cause of CVI and has significant socioeconomic consequences for both patients and for health services. The total additional cost of treating PTS, over 15 years, was approximately US $\$ 3,000$ in the United States. Additionally, PTS was responsible for 74 to $81 \%$ of all DVT treatment costs ${ }^{25}$. A study that analyzed data from patients with diagnoses of PE or DVT estimated that on average health services in the United States spent US\$7,000 per patient/year on PTS ${ }^{25}$. In Brazil, Ramacciotti et al. calculated that average annual cost was US\$ 400 for moderate cases and US\$1,200 for more serious PTS cases ${ }^{26}$. According to Susan and Kahn, around 20 to 50\% of patients with idiopathic DVT will develop PTS ${ }^{6}$. 


\section{POSTTHROMBOTIC SYNDROME VENOUS RECANALIZATION}

The pathophysiology of PTS is not entirely understood. However, it is probable that the presence of the thrombus releases inflammatory mediators which, together with the process of recanalization that takes place after a DVT episode, damage venous valves, leading to valve incompetence. Valve incompetence, persistent obstruction of veins by residual thrombus, or both, cause chronic venous hypertension, which leads to edema, to tissue hypoxia and even to ulcerations of the skin. Many different authors have proposed definitions of PTS based on combinations of clinical symptoms and signs, evidence of venous obstructions, elevated venous pressure or valve reflux, identified on the basis of ultrasound and/or plethysmograph findings. While a diagnosis of PTS cannot be made in the absence of these clinical signs, the majority of symptomatic patients exhibit valve incompetence, although many people with incompetence do not manifest PTS clinically $y^{6,27}$. Therefore, delayed recanalization after a thrombotic episode appears to be an important predictor of PTS development. However, the time and rates that are favorable to restoration of the lumen of different thrombosed venous segments have yet to be well-defined. Sevitt ${ }^{28,29}$ have suggested that recanalization is part of the process of fibrocellular organization of the thrombus. They consider that this process involves contraction of the thrombus, multiple tears between the thrombus and the tunica intima, localized fibrinolysis and fragmentation of the thrombus after cellular invasion by newly formed vessels $^{28,29}$.

\section{RECANALIZATION AND NEOANGIOGENESIS}

Wakefield et al. reported the results of on an experimental study that suggested that neoangiogenesis occurs during the process of organization of a thrombus, resulting in recanalization of occluded vessels ${ }^{30}$. Along the same lines, other authors have claimed that recanalization is part of the physiological process of thrombus remodeling. Labropoulos et al. studied the remodeling process in veins of the calf and found that length, lysis patterns and the location of thrombi are all factors that affect this process $^{31}$. Furthermore, Labropoulos et al., and Barros et al. have observed flow patterns that fit the profile of arteriovenous fistulae (AVF) in the thrombus interior as part of neovascularization after acute DVT episodes ${ }^{32,33}$. The spontaneous arterial flow that can be identified by color duplex mapping of thrombosed veins during the first weeks after an acute event appears to be secondary to the inflammation and neovascularization that occur after formation and remodeling of a thrombus ${ }^{32}$. Pulsating flow in the interior and adjacent to a thrombus can be identified by the observation of aliasing (which appears as a mixture of colors) and is characterized by a spectral curve with high end-diastolic velocity and low resistance index (RI), which is a typical AVF presentation, as illustrated below in Figures 1 and 2.

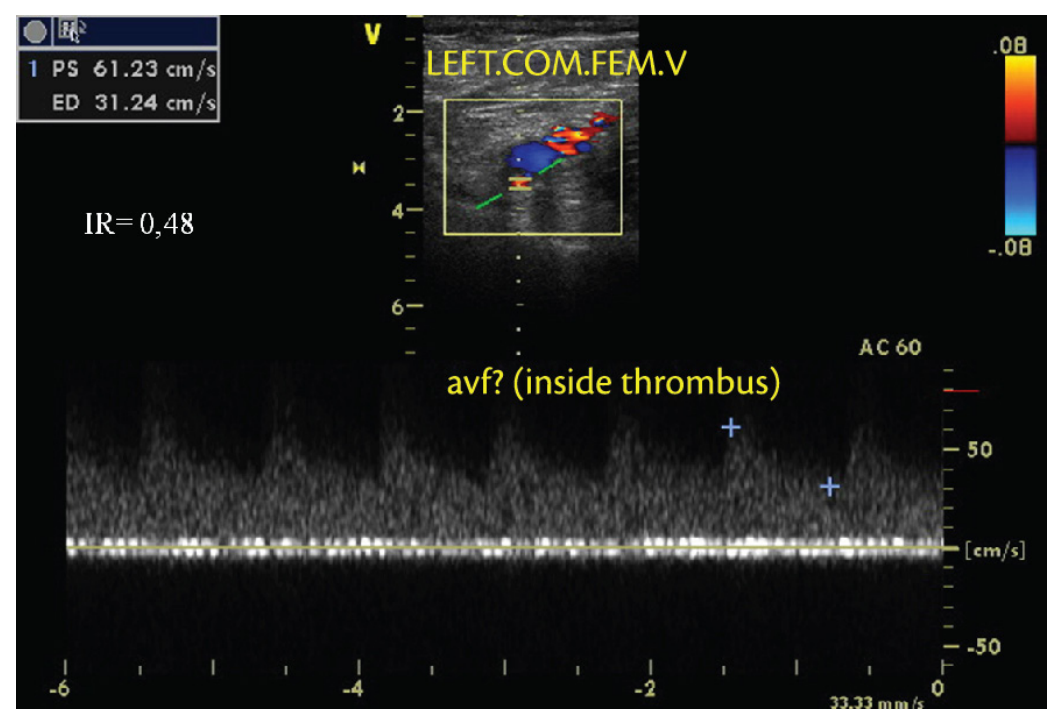

Figure 1. Color duplex mapping (cross-section) of the acutely thrombosed left common femoral vein. The vein exhibited pulsating flow, increased end-diastolic velocity, low resistance index and absence of normal physiological flow. These flow characteristics are consistent with an AVF. 


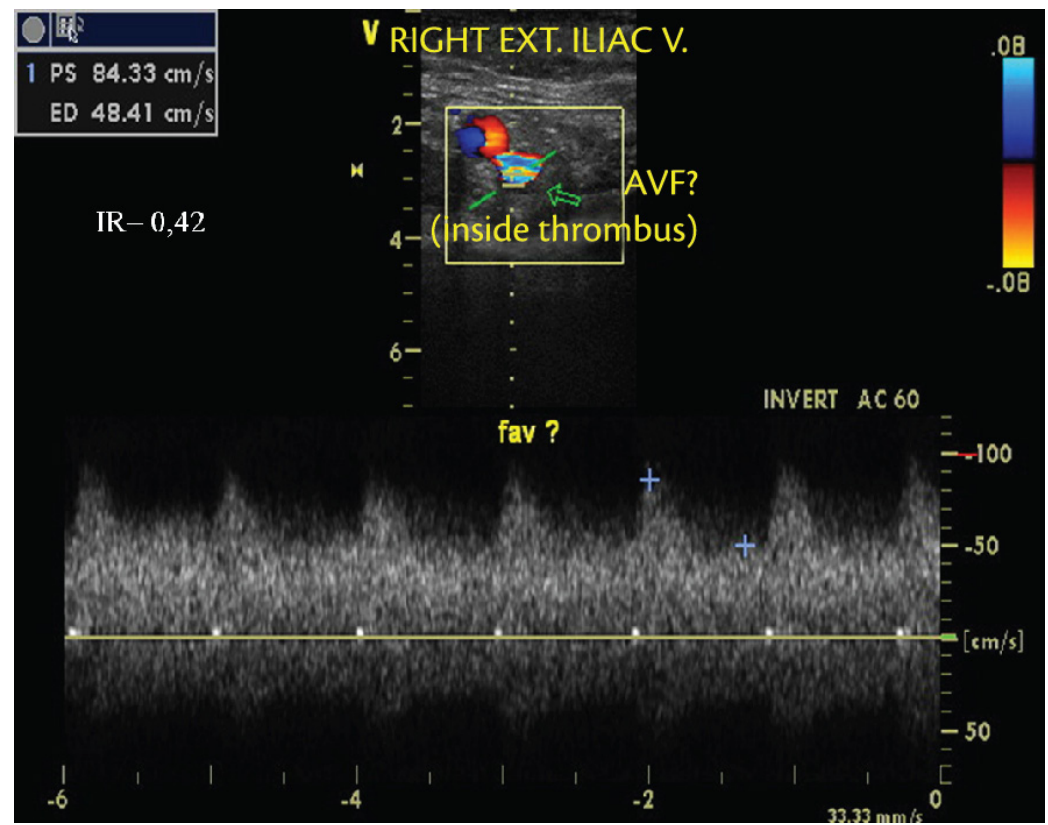

Figure 2. Color duplex mapping (cross-section) of the acutely thrombosed right external iliac vein. The vein exhibited pulsating flow, increased end-diastolic velocity, low resistance index and absence of normal physiological flow. These flow characteristics are consistent with an AVF.

\section{CONCLUSIONS}

In the past, studies employing serial phlebographic examinations gave the impression that recanalization was a late reaction, occurring over periods varying from 6 months to years after the acute event ${ }^{34}$. However, contemporary research reported by several authors ${ }^{25,34}$ who have employed CDM shows that the recanalization of thrombi in lower extremities with DVT is not a slow process, as was previously believed. Killewich et al. have published evidence that lysis of the thrombus and recanalization of venous segments can be observed on CDM in the first week after initial diagnosis ${ }^{35}$. Studies using phlebography to monitor the course of DVT have become less common because of its invasivity. Color duplex mapping has therefore expanded the possibilities for studying the natural history of DVT, because it makes it possible to conduct an unlimited number of sequential scans, thereby revealing patterns of events in the natural history of DVT that are different to what has been suggested in the past. Color duplex mapping also provides the possibility of using methods to quantify the recanalization process, such as the thrombotic score described by Porter et al. ${ }^{36}$ and the venous compressibility test using an ultrasound transducer described by Prandoni et al. ${ }^{37}$. It can therefore be considered that color duplex mapping has become the new gold standard method in phlebology.

\section{REFERENCES}

1. Maffei FHA, Rollo HA. Trombose venosa profunda dos membros inferiores: incidência, patogenia, patologia, fisiopatologia e diagnóstico. In: Maffei FHA, Lastória S, Yoshida WB, Rollo HA, Gianini M, Moura R, editors. Doenças Vasculares Periféricas. Rio de Janeiro: Guanabara Koogan; 2008. p. 1557-78.

2. Caggiati A, Bergan JJ, Gloviczki P, Jantet G, Wendell-Smith $\mathrm{CP}$, Partsch $\mathrm{H}$. Nomenclature of the veins of the lower limbs: an international interdisciplinary consensus statement. J Vasc Surg. 2002;36(2):416-22. PMid:12170230. http://dx.doi. org/10.1067/mva.2002.125847

3. Caggiati A, Bergan JJ, Gloviczki P, Eklof B, Allegra C, Partsch $\mathrm{H}$. Nomenclature of the veins of the lower limb: extensions, refinements, and clinical application.J Vasc Surg. 2005;41(4):719-24. PMid:15874941. http://dx.doi.org/10.1016/j.jvs.2005.01.018

4. Lastoria S, Sobreira M L. Tromboflebite superficial. In: Maffei F, Lastória S, Yoshida W, Rollo H, Gianini M, Moura R, editors. Doenças Vasculares Periféricas. Rio de Janeiro: Guanabara Koogan; 2008. p. 1547-56.

5. Sobreira ML, Maffei FH, Yoshida WB, et al. Prevalence of deep vein thrombosis and pulmonary embolism in superficial thrombophlebitis of the lower limbs: prospective study of 60 cases. Int Angiol. 2009;28(5):400-8. PMid:19935595.

6. Susan R, Kahn SR. The post-thrombotic syndrome: the forgotten morbidity of deep venous thrombosis. J Thromb Thrombolysis. 2006;21(1):41-8. PMid:16475040. http://dx.doi. org/10.1007/s11239-006-5574-9

7. Tófano VAC. Avaliação clínica e ultrassonográfica tardia de pacientes com trombose venosa prounda, portadores de trombofilia. [Tese]. Botucatu: Universidade Estadual Paulista; 2008. p. 169. 
8. Matida CK. Trombose venosa profunda dos membros inferiores em crianças e adolecentes tratados em um único centro no Brasil: epidemiologia e evolução. [Tese]. Botucatu: Universidade Estadual Paulista; 2008. p. 91.

9. Fowkes FJ, Price JF, Fowkes FG. Incidence of diagnosed deep vein thrombosis in the general population: systematic review. Eur J Vasc Endovasc Surg. 2003; 25(1):1-5. http://dx.doi.org/10.1053/ ejvs.2002.1778

10. Naess IA, Christiansen SC, Romundstad P, Cannegieter SC, Rosendaal FR, Hammerstrom J. Incidence and mortality of venous thrombosis: a population-based study. J Thromb Haemost. 2007;5(4):692-9. PMid:17367492. http://dx.doi. org/10.1111/j.1538-7836.2007.02450.x

11. Hasson PO, Welin L, Tibblin G, Eriksson H. Deep vein thrombosis and pulmonary embolism in the general population. The study of men born in 1913. Arch Int Med. 1997;157:1665-70. http://dx.doi. org/10.1001/archinte.1997.00440360079008

12. White RH, Zhou H, Romano PS. Incidence of idiopathic deep venous thrombosis and secundary thromboembolism among ethnic groups in California. Ann Int Med. 1998;128:737-40. http:// dx.doi.org/10.7326/0003-4819-128-9-199805010-00006

13. Nordström $M$, Lindblad B, Bergqvist $D$, Kjellström T. A prospective study of the incidence of deep vein thrombosis within a defined urban population. J Int Med. 1992;232:155-260. http://dx.doi. org/10.1111/j.1365-2796.1992.tb00565.x

14. Oger E for the EPI-GETBO Study Group. Incidence of venous thromboembolism: A community-based in Western France. Thromb Haemost. 2000;83:657-60. PMid:10823257.

15. Hull R, Hirsh J, Sackett DL, et al. Clinical validity of a negative venogram in patients with clinically suspected venous thrombosis. Circulation. 1981;64(3):622-5. PMid:7261292. http:// dx.doi.org/10.1161/01.CIR.64.3.622

16. Strandness DE Jr. History of ultrasonic duplex scanning. Cardiovasc Surg. 1996;4(3):273-80. http://dx.doi. org/10.1016/0967-2109(96)00001-4

17. Wells PS, Anderson DR, Rodger M, et al. Evaluation of D dimer in the diagnosis of suspected deep-vein thrombosis. N Engl J Med. 2003;349:1227-35. PMid:14507948. http://dx.doi. org/10.1056/NEJMoa023153

18. Goodacre S, Sutton AJ, Sampson FC. Meta-analysis: The value of clinical assessment in the diagnosis of deep venous thrombosis. Ann Intern Med. 2005;143(2):129-39. PMid:16027455. http:// dx.doi.org/10.7326/0003-4819-143-2-200507190-00012

19. Bernardi E, Prandoni P, Lensing AW, et al. D-dimer testing as an adjunct to ultrasonography in patients with clinically suspected deep vein thrombosis: prospective cohort study. The Multicentre Italian D-dimer Ultrasound Study Investigators Group. BMJ. 1998;317(7165):1037-40. PMid:9774286 PMCid:PMC28685. http://dx.doi.org/10.1136/bmj.317.7165.1037

20. Guyatt GH, AkI EA, Crowther M, Gutterman DD, SchünemannHJ. Antithrombotic therapy and prevention of thrombosis, 9th ed: American College of Chest Physicians Evidence-Based Clinical Practice Guidelines. Chest. 2012;141(2)(Suppl):7S-47S.

21. Watson LI, Armon MP. Thrombolysis for acute deep vein thrombosis. Cochrane Database Syst Rev. 2004;(4):CD002783. PMid:15495034.

22. Vedantham S. The Attract Study (Acute Venous Thrombosis: Thrombus removal with adjunctive catheter-directed thrombolysis). St. Louis: Washington University, School of Medicine; 2010.

23. Van Ramshorst B, Van Bemmelen PS, Hoeneveld H, Faber JA, Eikelboom BC. Thrombus regression in deep venous thrombosis. Quantification of spontaneous thrombolysis with duplex scanning. Circulation. 1992;86(2):414-9. PMid:1638710. http:// dx.doi.org/10.1161/01.CIR.86.2.414

24. Krupski WC, Bass A, Dilley RB, Bernstein EF, Otis SM. Propagation of deep venous thrombosis identified by duplex ultrasonography. J Vasc Surg. 1990;12(4):467-74. PMid:2214041.

25. Ashrani AA, Heit JA. Incidence and cost burden of post-thrombotic syndrome. J Thromb Thrombolysis. 2009; 28(4):465-76.

26. Ramacciotti E, Gomes M, De Aguiar ET, et al. A cost analysis of the treatment of patients with post-thrombotic syndrome in Brazil. Thromb Res. 2006; 118(6):699-704. PMid:16417913. http://dx.doi. org/10.1016/j.thromres.2005.12.005

27. Kahn SR, Ginsberg JS. Relationship between deep venous thrombosis and the postthrombotic syndrome. Arch Intern Med. 2004;164(1):17-26. PMid:14718318. http://dx.doi. org/10.1001/archinte.164.1.17

28. Sevitt S. The vascularisation of deep-vein thrombi and their fibrous residue: a post mortem angio-graphic study. J Pathol. 1973;111(1):1-11. PMid:4757506. http://dx.doi. org/10.1002/path.1711110102

29. Sevitt $\mathrm{S}$. The mechanisms of canalisation in deep vein thrombosis J Pathol. 1973;110(2):153-65. PMid:4125876. http://dx.doi. org/10.1002/path.1711100207

30. Wakefield TW, Linn MJ, Henke PK, et al. Neovascularization during venous thrombosis organization: a preliminary study. J Vasc Surg. 1999;30(5):885-92. http://dx.doi.org/10.1016/ S0741-5214(99)70013-3

31. Labropoulos N, Kang SS, Mansour MA, Giannoukas AD, Moutzouros V, Baker WH. Early thrombus remodelling of isolated calf deep vein thrombosis. Eur J Vasc Endovasc Surg. 2002;23(4):344-8. PMid:11991697. http://dx.doi.org/10.1053/ ejvs.2002.1608

32. Labropoulos N, Bhatti AF, Amaral S, et al. Neovascularization in acute venous thrombosis. J Vasc Surg. 2005;42(3):515-8. PMid:16171599. http://dx.doi.org/10.1016/j.jvs.2005.05.036

33. Barros F, Pontes S, Silva W, Prezzote B, Sandri J. Identificação pelo eco-doppler de fístula arteriovenosa na trombose venosa profunda.J Vasc Bras. 2006;5(3):224-8. http://dx.doi.org/10.1590/ S1677-54492006000300012

34. Bergvall U, Hjelmstedt A. Recanalisation of deep venous thrombosis of the lower leg and thigh. A phlebographic study of fracture cases. Acta Chir Scand. 1968;134(3):219-28. PMid:5730893.

35. Killewich LA, Macko RF, Cox K, et al. Regression of proximal deep venous thrombosis is associated with fibrinolytic enhancement. J Vasc Surg. 1997; 26(5):861-8. http://dx.doi.org/10.1016/ S0741-5214(97)70101-0

36. Porter JM, Moneta GL; International Consensus Committee on Chronic Disease. Reporting standards in venous disease: An update. J Vasc Surg. 1995;21:635-45. http://dx.doi.org/10.1016/ S0741-5214(95)70195-8

37. Prandoni P, CogoA, Bernardi E, et al. A simple ultrasound approach for detection of recurrent proximal-vein thrombosis. Circulation. 1993;88:1730-5. PMid:8403319. http://dx.doi. org/10.1161/01.CIR.88.4.1730 
Correspondence Gustavo Muçouçah Sampaio Brandão

FMB-UNESP

Distrito de Rubião Júnior, $\mathrm{s} / \mathrm{n}$ - Anexo verde

CEP 18618-970 - Botucatu (SP), Brazil Fone: +55 (14) 3811-6229

E-mail:gubrandao@terra.com.br

Author's information

GMSB is MSc and PhD candidate at Department of Surgery and Orthopedics, is Vascular surgeon and ultrasonographist;

Collaborating professor, Discipline of Vascular and Endovascular Surgery, Faculdade de Medicina de Botucatu at Universidade Estadual Paulista "Julio de Mesquita Filho" - UNESP.

MLS is assistant professor, Discipline of Vascular and Endovascular Surgery, is Chief, Service of Vascular and Endovascular Surgery at Department of Surgery and Orthopedics, is Chief, Vascular Laboratory, Faculdade de Medicina de Botucatu at Universidade Estadual Paulista "Julio de Mesquita Filho" - UNESP.

HAR is adjunct, tenured professor, Discipline of Vascular and Endovascular Surgery, Department of Surgery and Orthopedics at Faculdade de Medicina de Botucatu, UNESP.

Author's contributions Conception and design: GMSB Analysis and interpretation: N/A Data collection: N/A

Writing the article: GMSB Critical revision of the article: MLS, HAR Final approval of the article*: GMSB, MLS, HAR

Statistical analysis: N/A Overall responsibility: HAR Obtained funding: None. *All authors should have read and approved of the final version of the article submitted to I Vasc Bras. 